\title{
An Exploration of Emotional Intelligence and Market Segmentation, Targeting and Positioning in Selected Central Business Districts in Nigeria
}

\author{
Ezekiel Tom Ebitu \\ Department of Marketing, Faculty of Management Sciences \\ University Of Calabar, Calabar, Nigeria
}

Tel: 234-803-945-1333Ｅ-mail: Edidiongebitu@yahoo.com

Patrick Awok Mbum (Corresponding author)

Department of Marketing, Faculty of Management Sciences

University Of Calabar, Calabar, Nigeria.

Tel: 234-703-182-6974_E-mail: Mbumpat69@gmail.com

\author{
Abigail Edem Okon \\ Department of Guidance and Counseling, Faculty of Education \\ University of Calabar, Calabar, Nigeria \\ Tel: 234-803-676-2883 E-mail: Okonabigail@yahoo.com
}

Received: September 13, $2011 \quad$ Accepted: October 13, $2011 \quad$ Published: June 1, 2012

doi:10.5539/ijms.v4n3p173 URL: http://dx.doi.org/10.5539/ijms.v4n3p173

\begin{abstract}
Organizational politics, consumers' behaviors and buying process coupled with utter ignorance of the benefits derivable from the profound insight and knowledge of emotional intelligence to market segmentation, targeting, and positioning triggered this investigation. 1,500 questionnaires were administered and nine hundred (900) retrieved, representing 60\%. Psychometric properties were tested and improved upon using exploratory, descriptive, confirmatory factor analysis, analysis of internal consistency and reliability. Three models and hypotheses were developed and tested at $p<0.05$, and regression analysis used to determine the coefficient of $r^{2}$ $x_{1} \mathrm{ji}, \mathrm{r}^{2} \mathrm{x}_{2} \mathrm{ji}$ and $\mathrm{R}^{2}$ respectively. The streams of hypotheses tested buoyed credence to the empirical consequences of the correlationship with emotional intelligence predisposing an effective mechanism for market segmentation, targeting and positioning in the Nigerian four geo-political regions.

Nonetheless, the low values of $47 \%, 49 \%$ and $26 \%$ regression is a corollary for the impecunious applications of the skills and competencies embedded in emotional intelligence prepared for marketers to launch segmentation, targeting and positioning (STP) as marketing strategies.
\end{abstract}

Keywords: Central business districts, Demographic, Emintel, Geographic, Psychographic, STP

\section{Introduction}

Understanding how consumer preference, consumer choice, consumer learning, consumer behavior and buying process evolve over time is the kernel and heart of strategic marketing. A marketer can rarely satisfy everyone in a market because needs pre-exist marketers. Marketers based on consumers needs accompanied by other social factors influence wants and demands using several promotion tools or mixes, therefore, marketers start by dividing the market into segments and targets pursued (Kotler and Keller 2009.53). For marketers to get to the bottom of these seeming challenges, the application of emotional intelligence model to identify and profile distinct groups of buyers who are likely to require varying products, services or ideas mix which is the 
examination of demographic, psychographic and behavioral differences among buyers becomes irresistible (Etzel, Walker and Stanton 2001.150).

So what is emotional intelligence and what is its association with market segmentation, targeting and positioning (STP) strategies? Emotional intelligence (Emintel) according to Goleman (1995.4) describes the ability, capacity and skills to identify, assess, manage and control the feelings of oneself, of others and of groups. These feelings include joy, anger, mood, mental state, likes, dislikes, anguish and sadness. Several related studies conducted on emotional intelligence (emintel) correlated positively that emotional intelligence is not only critical in laying solid foundation in literacy, computation, building strong personal qualities, interpersonal and intrapersonal relationship, social and personal competencies, but in developing, influencing and sustaining effective relationship management, customer relationship management, management of people, events and activities and group relationship,(Cherniss and Goleman in Bennis, et al. 2006.400 and Dattner 2005).

Bradberry and Greaves (2009.219) posited that emotional intelligence is the instinctive capacity to accurately identify and understand one's own emotional reactions and those of others with respect to areas of responsibility, accountability, self-esteem, sociability, self-management, probity, integrity and honesty. Bar-on and Parker (2009.41) reiterated what Gardner (1983) and Tjosvold (1993.217) described as the ability and capacity to regulate one's emotions, using them effectively to make good and sound judgment. Emotional intelligence provides the bedrock for many workplace performance effectiveness and competency, including those applied in influencing others, connecting them, understanding their feelings and managing our own emotions (Ogunyemi 2010; Nwokah and Ahiauzu 2009; Petrides, Pita and Kokkinaki 2007.15; Mikolajczak and Leroy 2007.76; Salovey and Grewal 2005.29; Adeyemo and Ogunyemi 2002).

These assertions lead us to James-Lange theory of emotions which William James and Carl Lange postulated that emotion begins when we perceive a scenario of a sort (Gleitman, Fridlund and Reisberg 2004.450, Darwin 1872 and Thorndike 1920). James-Lange theory of emotions states that emotions are interpreted based on physiological reactions to events such as events $\rightarrow$ arousal $\rightarrow$ interpretation $\rightarrow$ emotion. This theory was then replaced by Cannon-Bard theory stating the opposite. According to Ellsworth (1994) the later theory stated that physiological changes are caused by a bilge of emotions. The third theory of emotions was Schachter-Singer two factor theories that states cognitions are used to interpret the meaning of physiological reactions to outside events (Johnsen, Tranel, Lutgendorf, and Adolphs 2009).

\subsection{Statement of the Problem}

In this investigation, the researchers suspect that part of the solution to STP marketing strategies, and unsuccessful hard sell resulting to some identifiable marketing failures is to examine marketer's critical success and failure variables. Emotional intelligence of marketers may be a veritable weapon for problem solving and impecunious market performance crisis resolution.

So far, these researchers are unaware of any existence of research works related to this study carried out in Nigeria. However, those available deal with occupational stress (Aremu, et al 2011 and Ogunyemi, 2010); marketing effectiveness and efficacy (Nwokah and Ahiauzu 2009, Adeyemo and Ogunyemi 2002). Others are Cherniss and Adler (2000), Davis, Stankor and Roberts (1998), Gardner (1983), Goleman (2001), Salovey and Mayer (1990), Steinberg (2002) and Thorndike (1920) have been reviewed for the purpose of this study.

Hence, this study can heuristically examine three strategic core concepts in marketing: segmentation, targeting and positioning (STP) under the following:

1) Whether marketers fully understand the concept of emotional intelligence and its application to market segment, target, and positioning, and

2) Whether application or non-utilization of emotional intelligence can in way contribute to improving marketers' performance and competency.

\subsection{Research Questions}

1) To what extent is emotional intelligence a determinant factor of the choice of market segmentation?

2) What emotional intelligence factor influence market targeting?

3) To what extent can emotional intelligence variables impact on market positioning?

\subsection{Research Hypothesis}

Ho $_{1}$ There is no significant relationship between an emotionally intelligent marketer and the choice of market segments. 
$\mathbf{H o}_{2}$ Emotional intelligence has no significant relationship with market targeting.

$\mathrm{Ho}_{3}$ There is no significant difference between emotional intelligence and effective market positioning.

\section{Theoretical Paradigms}

\subsection{Emintel Evolution}

In recent time, warnings about capitalist threat are more likely to come from business men and women than politicians. This is due to the magic of the marketplace to democratic societies and new massive wave of democratic agitations across the globe. Consequent on this premise, marketers ought to effectively strategize using every available methodology to optimize profitability and market efficiency.

The origin, development and influences of emotional intelligence (Emintel) and market segmentation, targeting and positioning is vague. However, Dattner (2005) posited that concepts of intelligence have evolved over the last 100 years. His work revealed that in the 1900s, Alfred Binet administered tests to French school children to determine their IQ. In 1918, the first large IQ tests were administered to US Army recruits. In 1930s, Thorndike postulated social intelligence. In the 1940s Wechsler put forth the theory of non-intellective, intelligence and between 1950 and 1958; Wechsler moderated Ohio state studies on "task" versus "consideration" and developed Wechsler Audit intelligence scale (WAIS). In 1983, Howard Gardener's "Frames of Mind" was published. And from 1990 to 2003, there have been a flurry of publications. Salovey and Mayer (1990) and Goleman (1995) conducted studies on emotional intelligence.

However, in 1966, Leuner conducted a study of emotional intelligence and its effect on job performance. In 1985, Wayne Payne dissertation was on "A study of Emotion: Developing Emotional Intelligence". This work threw more light on emotional intelligence; though, Leuner (1966) had done some work on emotional intelligence. Later on, in 1989, Greenspan presented emotional intelligence model, Salovey and Mayer (1990), Goleman (1995 and 2000). Salovey and Mayer (1990) postulated the three main models of emotional intelligence including:

$\rightarrow$ Ability emotional intelligence

$\rightarrow$ Mixed emotional intelligence, and

$\rightarrow$ Trait emotional intelligence

AMT Emintel model

Goleman's work further identified five models of emotional intelligence consisting of:

$\rightarrow$ Knowing your emotions

$\rightarrow$ Governing your own emotions

$\rightarrow$ Motivating yourself

$\rightarrow$ Recognizing and understanding other people's emotion's and

$\rightarrow$ Managing relationships, i.e. the motions of others.

(Mayer, Caruso and Salovey 2000.338, Steinberg 1985.285, van Velson, Taylor and Leslie 1993.263, Walton and McKersie 1965.249, Druskat and Wolf 2001.119, Copper and Sawaf 1997.308, and David, Stankor and Roberts 1998.112).

To Rahim and Psenicka (2002), emotional intelligence is a model that can be applied in resolving organizational conflicts. Adeyemo and ogunyemi (2011) study stressed that under stressful situations in organizations, some preventive strategies to enhance employees stability is emotional intelligence and self-efficacy. They concluded that this include helping staff develop competencies of perception, appraisal and expression of emotion that will facilitate sound thinking, understanding, and improving their knowledge to reduce occupational stress.

Ogunyemi (2010) established that the EQ is skills-oriented cluster concept and that these skills should be learned at elementary schools. He identified the skills to include self-control, zeal, persistence and self motivation.

On emotional intelligence and marketing effectiveness, Nwokah and Ahiauzu (2009) found a strong association between emotional intelligence and marketing effectiveness especially corporate organizations in Nigeria.

In a separate study conducted by Aremu, Parkes and Johnston (2011), the research results corroborated the data gathered and analyzed that emotional intelligence could effectively moderate attitudinal measures on police corruption and the verdict was that emotional intelligence as a catalyst can be used to promote integrity-based policing in Nigeria. 


\subsection{Structure of Emotional Intelligence}

According to Goleman (1998) emotional intelligence refers to the capacity for recognizing our own feelings and those of others, for motivating ourselves and for managing emotions well in ourselves and our relationships.

Managing emotions of others, according to Salovey and Mayer (1990) as emphasized by Goleman (1998) requires two key skills: personal and social competence. Self-awareness and self-management are regulated by personal competence and social awareness and relationship management is governed by social competence. It is the latter that inform this study. Empathy, organization awareness, service orientation, inspiring leadership change catalyst, influence, conflict management, teamwork and collaboration fit into market segmentation, targeting and positioning (STP) strategies.

\subsection{Market Segmentation, Targeting and Position (STP) Strategies}

Any market strategic planning process flows from a mission and vision statement to the selection of target markets and the formulation of specific marketing mix and positioning objective for a product, service or idea (Kotler and Keller 2009. 268 and Porter 1985. 231)

Market segmentation is adaptive strategy capable of shaping the configuration of the value chain. Nwokoye (2000) agreed with Agbonifoh, Ogwo and Nnolim (1998) that through marketing strategy, firm provide higher value to customer by developing a market mix that addresses specific needs and concerns of the segment. In other words, the firm creates monopolistic or oligopolistic market conditions and utilizes various curves of demand for a specific product category which explains Bertrand's model of reaction curves and price and output determination under joint profit maximization scheme (Ahuja 2010 and Jhingan 2003.463). Based on this theory, price is broadened to include all $4 \mathrm{ps}$. A flurry of literature supports the argument that segmentation process consist of:

$\rightarrow$ Segment identification,

$\rightarrow$ Segment selection, and

$\rightarrow$ Creation of marketing mixes for target market

Once a market segment is selected, a generic competitive advantage strategy should be adopted. According to Kotler (1994.293), the only sustainable generic strategy is market differentiation, competitive advantage and low cost strategies geared towards customer value, provide perceived value and should be made difficult to copy. It is after selecting this market target Gunter and Furnham (1992) prescribed that market positioning in the minds of value customer can be developed. According to Aakar (1996), positioning is the part of the brand identity and value proposition that is to be actively communicated to the target audience and that demonstrates an advantage over competing brands, including brand objectives, target marketing and brand vision. (Aaker 1992), Kotler and Keller (2009) posited that positioning is the point where the bundles of attribute join to form one irresistible concept capturing the essence that target audience seek in the product category.

\section{Methodology}

This study spotlight key central business district (CBDs) in Abuja, Kano, Lagos and Port Harcourt cities of Nigeria where the bulk of our subjects or respondents do businesses.

A descriptive survey research design was employed. Data for this study were collected from a randomized sample drawn from banks, insurance houses, factories, oil, gas and other allied companies.

The sampled population was drawn from Akpangbo, Lagos main island, Lekki, Victoria Island, TransAmadi, Bonny Island, Okirika, Brass, Garki, Wuze Zone II, Gwagwalada, Bompai, Kano, and so on, Nigerian towns and cities of Abuja, Kano, Lagos and Port Harcourt. These populations are homogenous and therefore reflected the Nigerian territorial geography. Abuja $\rightarrow$ Central; Kano $\rightarrow$ North; Lagos $\rightarrow$ West and Port Harcourt $\rightarrow$ East of Nigeria for research convenience.

A simple, purposive stratified randomization was used to select 1,500 of 5,476 populations. One thousand five hundred $(1,500)$ questionnaires were mailed, 900 of the questionnaires were retrieved, i.e. $60 \% .13 \%$ came from Abuja ( $\mathrm{n}=117) ; 25 \%$ from Kano $(\mathrm{n}=225) ; 43 \%$ from Lagos $(\mathrm{n}=387)$ and $19 \%$ from Port Harcourt $(\mathrm{n}=171)$.

Average biological age of the respondents in the four regions ranged between 35.68-46.86 ( $\mathrm{SD}=6.09-12.34)$. Their average full-time work experience in years ranged between $8.45-15.23(\mathrm{SD}=5.06-11.42)$. The percentage of male respondents in the four regions ranged between $52.3 \%-91.6 \%$. Average full-time work experience (in years) of the respondents with their present supervisors fall between $3.44 \rightarrow 9.85$ (SD $=3.21-$ $5.43)$. 
The five dimension of emotional intelligence was measured with a carefully crafted EMINTEL STP using 13 item instrument. It was designed by the researchers and validated by three Professors in the Faculty of Education and one Professor in Modern Languages who are psychometric experts. They did a critique on item-by-item basis using difficulty, ambiguousness and inconsistency criteria which were dropped, reframed or rephrased. The EMINTEL was designed using Likert 4 - point scale options. $4=$ Strongly Agree (SA), $3=$ Agree (A), 2 = Disagree (D) and 1 = Strongly Disagree (SD). Respondents' options elicited iterative process of exploratory and confirmatory factor analyses of the 13 - item instrument. Considerable attention was devoted to the study of published works on emotional intelligence on one hand and the core marketing strategies of segmentation, targeting and positioning on the other hand. Our sample is $(\mathrm{n}=900)$.

\section{Analysis of Data}

Four successive exploratory factor analyses were performed to pick: Decision Making Managers (DMM) $=128$ $(15 \%)$ Employed Supervisors/Operational Managers $(\mathrm{ES} / \mathrm{OM})=213(24 \%)$ Employed Senior Managers (ESM) $=286(32 \%)$ and Responsible Personnel/Managers $(\mathrm{RP} / \mathrm{M})=273(31 \%)$. After each factor analysis, the item that loaded or weighed less than 0.05 or and uninterruptable were either dropped or rephrased to arrive at the 13 item instrument based on the following table:

The analyses in table 1 scrutinized the mixed models of Goleman (1998.61) which identified self-awareness, self-management, social awareness and relationship management. The relationship management exudes the ability to inspire, influence, develop others, connect and manage conflicts. Bar-On (2006.118) agreed that emintel is concerned with effective understanding of oneself and others, relating well with people and adapting to and coping with the immediate surroundings to be more successful in dealing with environmental (marketing) demands (Nunally 1978.441, Joshua 2005.170, Lucy 2002.153 and Rahim and Psenicka 2002.308).

Using the given regression equation, a further analyses from the field work extracted from the questionnaire, the researchers determined separate multiple regressions and coefficients of determination to established the significant level at $\mathrm{P}<=0.05$.

1) Study the influence of emotionally intelligent marketer in relation to choice of market segment.

2) Investigate the relationship between emotional intelligence and market targeting, and

3) Examine the difference between emotional intelligence and effective market positioning.

\subsection{Interpretation}

$\gamma_{\mathrm{x} 1 \mathrm{j}}^{2} \Rightarrow$ implies that $47 \%$ of the market segment is obviously influenced by emotional intelligence (emintel) of marketers in designated centers (Abuja, Kano, Lagos and Port Harcourt) for this study.

$\gamma^{2} \times 2 j \Rightarrow$ implies that there is significant relationship between emotional intelligence and market targeting even though respondents had little or no knowledge of what emotional intelligence and the utilization of its skills can do in scooping target or concentrated audience.

$\mathrm{R}^{2} \Rightarrow$ This implies that most marketers are unaware and have not leverage on the competencies, skills and knowledge of emotional intelligence to select segments, target and position in the hearts, minds and strategically or conspicuously site where customers must necessarily locate you and do profitable market effective businesses.

\section{Summary and Conclusions}

The underlying implications of this study and the consequence is that, by using emotional intelligence, marketers can study, develop and acquire some competencies to encourage, craft and sustain own emotions, others emotions and group emotions and apply it to divide and select market compartments, target audience and position goods in the minds and hearts of the potential consumers (Gardner $1983 \mathrm{a}$ and b and Goleman 1995.7).

Self-regulations, self-awareness, self-motivation and that of group emotions correlate proportionately to market segmentation, targeting and positioning as empirically corroborated by (Mayer, Caruso and Salovey 2000.334; Nwokoye 2000.143; Rahim and Psenicka 2002.330 and Copper and Sawaf 1997.285 and substantiated by Curran, West and Finch 1996.26).

In the course of this investigation, thirteen factors: geographic, demographic, psychographic, behavioral/attitudinal, affluence/socialite group, market attractiveness, need based, access, product differentiation, product undifferentiating, market concentration, market cannibalization and perceptual mapping were advocated, and this directly correlated with the impact of marketers job effectiveness when applying emotional intelligence (emintel) in market segmentation, targeting and positioning (STP) marketing strategies 
(Cateora and Graham 2007.610, Banga and Sharma 2008.814, Kotler and Keller 2009.53 and Berkowitz, Kerin and Rudelius 1989.196).

Therefore, the challenge for the contemporary marketers who aspire to remain relevant in the competitive and globalised market as this study has empirically established a high-low $47 \%, 49 \%$ and $26 \%$ respectively, is to buy into the managerial concept of emotional intelligence to influence choice of market segmentation, targeting and positioning (Cherniss and Adler 2000; Adeyemo and Ogunyemi 2002; Nwokah and Ahiauzu 2009; Aremu, Parkes and Johnston 2011).

Marketers should sharpen their skills of problem solving, haggling tactics, bargaining strategies, communication proficiencies, and improving marketers' education with specific job related manpower development techniques (Aremu, Parkes and Johnston 2011; Adeyemo and Ogunyemi 2002; Bar-On and Parker 2000 and Aakes, 1992).

Marketers need competency training that are focused on the needs of customers and that these needs are excellently geared towards increasing job performance. These allusions support what Busari and Abass (2007.40) recommended that emotional intelligence training programme as an intervention strategy in curbing sexual anxiety and stress problems among fresh university students in South Western Nigeria is efficacious. The implications of the study findings, according to Adeyemo and Ogunyemi (2011.9) reinforces Akinboye, Akinboye and Adeyemo (2002.65) conclusions that emotional intelligence facilitate rationality, good thinking, understanding, empathy, and analyses feelings, passion and sensations, improving marketers' self-efficacy, using vicarious experiences, verbal plausibility, persuasion, active domain, market audience selection, anxiety management, market positioning in the hearts and minds of consumers that may lead to a sharp rise in sales revenue, profitability, market effectiveness and market stress-free operations.

Emotional intelligence - Emintel (inbound-focused) and market segmentation, targeting and positioning (STP) strategies (outbound-focused) are different yet complementary efforts with the objective of maximizing sales revenues, market shares, market efficiency and effectiveness and profit margins (Griffin and Hauser 1993; Burchill and Brodie 1997; Kahn 2005 and Bradly 2007).

The direction for future research of a related topic should unravel emotional intelligence and body language factors for effective communication to increase sales and revenue volume of corporate organizations with marketers in their employ in developing markets like Nigeria.

\section{References}

Aaker, D. (1992). Managing Brand Equity.

Adeyemo, D. A., \& Ogunyemi, B. (2002). Emotional intelligence and self-efficacy as predictors of occupational stress among academic staff in a Nigeria University. [Online] Available: http://www.leadingtoday.org/weleadinlearning/dao5.htm

Agbonifoh, B. A., Ogwo, O. E., \& Nnolim, D. A. (1988). Marketing in Nigeria: concept, principles and Decisions. Aba: Afritowers Ltd.

Ahuja, H. L. (2010). Advanced Economic Theory: Microeconomic Analysis (17th ed.). New Delhi: S. Chand \& Company Ltd.

Akinboye, J. O., Akinboye, D. O., \& Adeyemo, D. A. (2002). Coping with Stress in Life and Workplace. Lagos: Stirlin-Holden Publishers (Nigeria) Ltd.

Aremu, A. O., Parkes, F., \& Johnston, L. (2011). The moderating effect of emotional intelligence on the reduction of corruption in the Nigerian Police. [Online] Available: www.tandfonline.com/doi/full/10.1080/156/14/263.2010.536724//tab module

Banga, T. R., \& Sharma, S. C. (2008). Industrial Engineering and Management including Production Management. Nai Sarak, Delhi: Khanna Publishers.

Bar-on, R., \& Parker, J. D. A. (2000). The Handbook of Emotional Intelligence: Theory, Development, assessment, and application at home, school and in the workplace. San Francisco: Jossey-Bass.

Bennis, W. L. et al. (2006). Business: The Ultimate Resource (2nd ed). Suffolk, UK: Basic Books.

Berkowitz, E. N., Kerin, R. A., \& Rudelius, W. (1989). Marketing ( ${ }^{\text {nd }}$ ed.). Boston: Homewood-Irwin.

Bradberry,T., \& Greaves, J. (2009). Emotional Intelligence (2nd ed.). San Francisco: Publishers Group West.

Bradly, N. (2007). Marketing Research: Tools and Techniques. Oxford: Oxford University Press.

Burchill, G., \& Brodie, C.H. (1997). Voices into Choices. Madison, WI: Joiner Publications. 
Busari, A. O., \& Abass, A. O. (2007). Emotional Intelligence in Modifying Signs and Symptoms of Sexual Anxiety among Fresh University Students in South-Western Nigeria. International Journal of African and American Studies, 6(2).

Cateora, P. R., \& Graham, J. L. (2007). International Marketing (13th ed.). London: McGraw-Hill Irwin.

Cherniss, C., \& Adler, M. (2000). Promoting emotional intelligence effectiveness. Alexandria, VA: ASTD.

Copper, R. K., \& Sawaf, A. (1997). Executive EQ: Emotional Intelligence in Leadership and Organizations. New York: Grosset/Putnam.

Curran, P. J., West, S. G., \& Finch, J. F. (1996). The Robustness of Test Statistics to Nonnormality and Specification Error in Confirmatory Factor. Psychological Methods, 1(1), 16 - 29. http://dx.doi.org/10.1037//1082-989X.1.1.16

Davis, M., Stankor, L., \& Roberts, R. D. (1998). Emotional Intelligence: In search of an elusive construct. Journal of personality and social psychology, 989 - 1015. http://dx.doi.org/10.1037/0022-3514.75.4.989

Druskat, V. U., \& Wolf, S. B. (2001). Group Emotional Intelligence and its influence on group effectiveness. In Cherniss, C., \& Goleman, D. (2001), Emotional Intelligent workplace (pp. 132 - 155). San Francisco: Jossey-Bass.

Ellsworth, P. C. (1994). William James and Emotion: Is a Century of Fame Worth a Century of Misunderstanding. Psychological Review, 101(2), 222-229.

Etzel, M. J., Walker, B. J., \& Stanton, W. J. (2001). Marketing (12th ed.). New York: McGraw-Hill Irwin.

Gardner, H. (1983a). Frames of Mind: Theory of Multiple intelligence. New York: Basic Books.

Gardner, H. (1999b). Intelligence Reframed. New York: Basic Books.

Goleman, D. (1995). Emotional Intelligence. New York: Bantum Books.

Griffin, A., \& Hauser, J. (1993). The Voice of the Customer. Marketing Science, 12(1), 1-27. http://dx.doi.org/10.1287/mksc.12.1.1

Jhingan, M. L. (2003). Advanced Economic Theory: Micro-and Macroeconomics (12th ed.). New Delhi: Vrinda Publications (P) Ltd.

Johnsen, E. L., Tranel, D., Lutgendorf, S., \& Adolphs, R. (2009). A Neuroanatomical Dissociation for Emotion Induced by Music. International Journal of Psychophysiology, 72(1), 24-33. http://dx.doi.org/10.1016/j.jpsycho.2008.03.011

Joshua, T. M. (2005). Fundamentals of Test and Measurement in Education. Calabar, Nigeria: The University of Calabar press.

Kahn, K. B. (2005). The PDMA Handbook of New Product Development (2nd ed.). New Jersey: John Wiley \& Sons.

Kotler, P., \& Keller, K. L. (2009). Marketing Management (13th ed.). London: Pearson Prentice Hall.

Mayer, J. D., Caruso, D. R., \& Salovey, P. (2000). Selecting a measure of emotional intelligence. A case for ability scales. In Bar-On, R., \& Parker, J.D.A. (Eds.), The Handbook of Emotional Intelligence: Theory, development, assessment, and application at home, school and in Workplace. San Francisco: Jossey-Bass.

Mikolajzak, M., Luminet, O., Leroy, C., \& Roy, E. (2007). Psychometric properties of the Trait Emotional Intelligence Questionnaire. Factor structure, Reliability, Construct, and Incremental validity in a French-Speaking Population. Journal of Personality Assessment, $88(3), \quad 338-353$. http://dx.doi.org/10.1080/00223890701333431

Nunnally, J. C. (1978). Psychometric theory (2nd ed.). New York: McGraw-Hill.

Nwokah, G. N., \& Ahiauzu, A. I. (2009). Emotional Intelligence and Marketing Effectiveness. Marketing intelligence and planning, 27(7), 864-881.

Nwokoye, N. G. (2000). Modern Marketing for Nigeria: principles and practice (2nd Ed.). Onitsha - Nigeria: African-FEP Publishers Ltd.

Ogunyemi, Bola. (2010). Differential effectiveness of provocation, brainstorming and emotional mastery in fostering emotional intelligence (EQ) among Nigerian adolescents. Academic Leadership Journal, 8(3). 
Petrides, K. V., Pita, R., \& Kokkinaki, F. (2007). The location of trait emotional intelligence in personality factor space. British Journal of Psychology, 98, 273 - 289. http://dx.doi.org/10.1348/000712606X120618

Rahim A. A., \& Psenicka, C. (2003). A model of emotional intelligence and conflict management strategies: A study in seven countries. Pretoria, South Africa: EBSCO Publishing.

Steinberg, R. J. (1985). The triarchic Mind: A new theory of human intelligence. New York: Viking Publishing.

Thorndike, R. K. (1920). Intelligence and its uses. Harper's Magazine.

Van Velson, E., Taylor, S., \& Leslie, J. B. (1993). An examination of the relationships among self-perception, accuracy, self-awareness, gender and leader effectiveness. Human Resource Management, 32, 249 - 263. http://dx.doi.org/10.1002/hrm.3930320205

Walton, R. E., \& McKersie, R. B. (1965). A behavioral theory of labor negotiations: An analysis of a social interaction system. New York: McGraw-Hill.

Table 1. Confirmatory factor analysis of questionnaire by location

\begin{tabular}{|c|c|c|c|c|c|c|c|c|c|c|c|}
\hline S/N & Variable & Ratio & $\begin{array}{c}\text { Abuja } \\
\mathbf{n = 1 1 7}\end{array}$ & Ratio & $\begin{array}{c}\text { Kano } \\
\mathbf{n = 2 2 5}\end{array}$ & Ratio & $\begin{array}{c}\text { Lagos } \\
\mathbf{n = 3 8 7}\end{array}$ & Ratio & $\begin{array}{c}\text { Port-Harcourt } \\
\mathbf{n = 1 7 1}\end{array}$ & $\begin{array}{c}\text { Ratio } \\
\text { Aggregates } \\
\mathbf{n = 9 0 0}\end{array}$ \\
\hline 1. & DMM & 2.22 & 20 & 3.33 & 30 & 5.67 & 51 & 3.00 & 27 & 15.00 & 128 \\
\hline 2. & ES/OM & 3.00 & 27 & 6.56 & 59 & 9.56 & 86 & 4.56 & 41 & 24.00 & 213 \\
\hline 3. & ESM & 3.56 & 32 & 7.89 & 71 & 14.89 & 134 & 5.44 & 49 & 32.00 & 286 \\
\hline 4. & RP/M & 4.22 & 38 & 7.22 & 65 & 12.88 & 116 & 6.00 & 54 & 31.00 & 273 \\
\hline
\end{tabular}

Source: Field work

Table 2. Confirmatory factor analysis of the 13-item in split samples

\begin{tabular}{|c|c|c|c|c|c|}
\hline Item & Variables & $\begin{array}{l}\text { Analysis } \\
\text { Loading }\end{array}$ & $\begin{array}{c}\text { Samples } \\
\mathrm{t}\end{array}$ & $\begin{array}{l}\text { Holdout } \\
\text { Loading }\end{array}$ & $\begin{array}{c}\text { Sample } \\
\mathrm{t}\end{array}$ \\
\hline$\beta_{1}$ & Market Segmentation & & & & \\
\hline 1. & $\begin{array}{l}\text { Population density should be considered when } \\
\text { marketing. }\end{array}$ & 2.2266 & 274.00 & 20.0366 & 3007 \\
\hline 2. & Income level guide marketers & 1.5244 & 250.00 & 13.7195 & 2743 \\
\hline 3. & $\begin{array}{l}\text { Lifestyle of people should inform you where to } \\
\text { market products, etc. }\end{array}$ & 1.6553 & 272.00 & 14.9268 & 2985 \\
\hline 4. & Market audience should be hard-core brand loyalist. & 1.4379 & 236.00 & 12.9512 & 2500 \\
\hline $\boldsymbol{\beta}_{2}$ & Market Targeting & & & & \\
\hline 5. & Audience should be enlightened. & 1.5000 & 246.00 & 13.5000 & 2700 \\
\hline 6. & Avoid uninformed audience. & 1.3289 & 218.00 & 11.9634 & 2392 \\
\hline 7. & $\begin{array}{l}\text { It is more reliable dealing with tested market } \\
\text { ground. }\end{array}$ & 1.5000 & 246.00 & 13.5000 & 2700 \\
\hline 8. & Unaware audience may not be loyal. & 1.2561 & 206.00 & 11.3049 & 2260 \\
\hline$\beta_{3}$ & Market Positioning & & & & \\
\hline 9. & Do product differentiation. & 1.4146 & 232.00 & 12.7317 & 2546 \\
\hline 10. & Cannibalize by dropping unprofitable product line. & 1.4756 & 242.00 & 13.2805 & 2656 \\
\hline 11. & $\begin{array}{l}\text { Strategically win the hearts and } \\
\text { minds of consumers. }\end{array}$ & 1.7439 & 286.00 & 15.6951 & 3139 \\
\hline 12. & Need to emphasize products attributes. & 1.5853 & 260.00 & 14.2683 & 2853 \\
\hline 13. & Need to expressively appeal to focused audience. & 1.6585 & 272.00 & 14.9268 & 2985 \\
\hline
\end{tabular}

Source: Field work 
Table 3. Confirmatory model fit statistics

\begin{tabular}{|l|l|c|c|}
\hline S/N & Index & Analysis sample & $\begin{array}{c}\text { Holdout } \\
\text { sample }\end{array}$ \\
\hline 1. & Chi-square $\mathrm{X}^{2}(\mathrm{df}=898)$ & 19690.24 & 35560.98 \\
2. & Root mean square error of approximation (RMSEA) & 0.6124 & 0.8202 \\
3. & Goodness-of-fit-index (GFI) & 0.9632 & 0.94 \\
4. & Adjusted Goodness-of-fit index (AGFI) & 0.9124 & 0.87 \\
\hline
\end{tabular}

Table 4. Factor analyses correlations

\begin{tabular}{|l|c|c|c|c|}
\hline EMINTEL STP Sub-variables & 1 & 2 & 3 & 4 \\
\hline Core market values & 1.00 & $.79(19.9)$ & $.65(31.8)$ & $.95(36.7)$ \\
Consumer markets & $.86(45.2)$ & 1.00 & $.88(42.76)$ & $.79(29.9)$ \\
Classic stratagem & $.72(33.2)$ & $.76(31.9)$ & 1.00 & $.74(33.8)$ \\
Managing one's emotions & $.79(38.4)$ & $.81(36.84)$ & $.92(32.6)$ & $.81(36.7)$ \\
Managing relationship & $.94(56.5)$ & $.93(47.41)$ & $.75(27.9)$ & 1.00 \\
\hline
\end{tabular}

Note: $\mathrm{t}$ - values are in parentheses

Source: Analysis of field work

Table 5. Means, standard deviations and Cronbach $\alpha$ internal consistency, reliability across the four geographical regions in Nigeria

\begin{tabular}{|l|c|c|c|c|c|c|c|c|c|c|c|c|}
\hline Factor & \multicolumn{3}{|c|}{ Abuja } & \multicolumn{3}{c|}{ Kano } & \multicolumn{3}{|c|}{ Lagos } & \multicolumn{3}{|c|}{ Port - Harcourt } \\
\cline { 2 - 11 } & $\mathbf{X}$ & SD & $\mathbf{A}$ & $\mathbf{X}$ & SD & $\boldsymbol{\alpha}$ & $\mathbf{X}$ & SD & $\boldsymbol{\alpha}$ & $\mathbf{X}$ & SD & $\mathbf{A}$ \\
\cline { 2 - 11 } 1) Geographic & 4.5 & .86 & .97 & 4.05 & .69 & .83 & 3.20 & .79 & .86 & 4.7 & .06 & .90 \\
2) Demographic & 3.35 & .29 & .95 & 3.45 & .97 & .87 & 3.1 & .86 & .97 & 3.9 & .62 & .84 \\
3) Psychographic & 3.0 & .28 & .93 & 3.15 & .77 & .67 & 3.3 & .64 & .64 & 3.7 & .23 & .80 \\
4) Behavioral/Attitudes & 5.95 & .37 & .90 & 3.75 & .89 & .78 & 3.3 & .76 & .96 & 3.9 & .33 & .90 \\
5) Affluence/socialite group/class & 4.52 & .29 & .97 & 3.06 & .58 & .77 & 3.8 & .72 & .92 & 4.1 & .43 & .87 \\
6) Market attractiveness & 3.61 & .39 & .86 & 3.65 & .83 & .70 & 4.0 & .47 & .62 & 4.3 & .55 & .85 \\
7) Need-based group & 3.5 & .51 & .95 & 3.65 & .91 & .68 & 3.7 & .38 & .76 & 4.1 & .38 & .81 \\
8) Access & 3.4 & .17 & .96 & 3.12 & .71 & .60 & 3.6 & .83 & .90 & 4.1 & .05 & .88 \\
9) Product differentiation & 3.39 & .26 & .94 & 3.16 & .33 & .72 & 3.3 & .73 & .93 & 4.0 & 48 & .86 \\
10) Product undifferentiating & 3.95 & .27 & .95 & 3.08 & .70 & .84 & 4.6 & .74 & .83 & 4.5 & .03 & .87 \\
11) Product concentration & 3.24 & .28 & .91 & 3.18 & .78 & .73 & 3.9 & .58 & .91 & 3.7 & .16 & .80 \\
12) Market cannibalization & 3.24 & .29 & .87 & 3.35 & .93 & .70 & 3.7 & .68 & .94 & 3.4 & .46 & .79 \\
13) Perceptual map & 3.61 & .30 & .90 & 3.12 & .85 & .51 & 4.1 & .86 & .95 & 2.9 & .48 & .86 \\
\hline
\end{tabular}

Note: Abuja $=$ Capital City of Nigeria (Central Nigeria), Kano $=$ Far North of Nigeria, Lagos $=$ Nigeria Commercial nerve centre (West of Nigeria) and Port Harcourt = Seat of Oil and Gas (East of Nigeria) were purposively sampled for questionnaire administration and research convenience. There are states created by the Federal Republic of Nigeria and entrenched in the 1999 constitution. 
Table 6. Analysis of questionnaire

\begin{tabular}{|l|l|c|c|c|}
\hline S/N & Factors/Item & Segmentation & Targeting & Positioning \\
\hline 1. & Geographic & 251 & 223 & 219 \\
2. & Demographic & 311 & 210 & 102 \\
3. & Psychographic & 221 & 304 & 165 \\
4. & Behavioral & 180 & 127 & 291 \\
5. & Affluence & 310 & 118 & 196 \\
6. & Attractiveness & 137 & 270 & 145 \\
7. & Needs-Based & 148 & 172 & 270 \\
8. & Access & 161 & 91 & 145 \\
9. & Differentiation & 293 & 150 & 306 \\
10. & Undifferentiating & 142 & 165 & 362 \\
11. & Concentration & 162 & 200 & 329 \\
12. & Cannibalization & 145 & 185 & 344 \\
13. & Perceptual map & 150 & 195 & \\
\hline
\end{tabular}

Source: Field work

Table 7. Determination of separate regressions given eqn (1)

\begin{tabular}{|c|c|c|c|c|c|c|c|c|c|}
\hline ITEM & $\mathrm{Y}$ & $\mathrm{Y}^{2}$ & $\chi_{1}$ & $\chi_{1}^{2}$ & $\chi_{2}$ & $\chi_{2}^{2}$ & $\chi_{1} \mathrm{y}$ & $\chi_{2} y$ & $\chi_{1} \chi_{2}$ \\
\hline 1. & 251 & 63001 & 223 & 49729 & 219 & 47961 & 55973 & 54969 & 48837 \\
\hline 2. & 311 & 96721 & 210 & 44100 & 102 & 10404 & 65310 & 31722 & 21420 \\
\hline 3. & 221 & 48841 & 304 & 92416 & 165 & 27225 & 67184 & 36465 & 50160 \\
\hline 4. & 180 & 32400 & 127 & 16129 & 291 & 84681 & 22860 & 52380 & 36957 \\
\hline 5. & 310 & 96100 & 118 & 13924 & 196 & 38416 & 36580 & 60760 & 23128 \\
\hline 6. & 137 & 18769 & 270 & 72900 & 145 & 21025 & 36990 & 19865 & 39150 \\
\hline 7. & 148 & 21904 & 172 & 29584 & 303 & 91809 & 25456 & 44844 & 52116 \\
\hline 8. & 161 & 25921 & 91 & 8281 & 270 & 72900 & 14651 & 43470 & 24570 \\
\hline 9. & 293 & 85849 & 150 & 22500 & 145 & 21025 & 43950 & 42485 & 21750 \\
\hline 10. & 142 & 20164 & 165 & 27225 & 306 & 93636 & 23430 & 43452 & 50490 \\
\hline 11. & 162 & 26244 & 200 & 40000 & 362 & 131044 & 32400 & 58644 & 72400 \\
\hline 12. & 145 & 21025 & 185 & 34225 & 329 & 108241 & 26825 & 47705 & 60865 \\
\hline \multirow[t]{2}{*}{13.} & 150 & 22500 & 195 & 38025 & 344 & 118336 & 29250 & 51600 & 67080 \\
\hline & 2611 & 1149439 & 2410 & 489038 & 3177 & 866703 & 480859 & 589365 & 568923 \\
\hline
\end{tabular}

Note: For Regression y on $\chi_{1}$ (Emotional Intelligence: Market segmentation).

$$
\begin{gathered}
\mathrm{b} \chi_{1 \mathrm{j}}=\frac{\mathrm{n} \Sigma \chi_{1 \mathrm{j}} \mathrm{y}-\Sigma \chi_{1 \mathrm{j}} \Sigma \mathrm{y}}{\mathrm{n} \Sigma \chi_{1 \mathrm{j}}^{2}-\left(\Sigma \chi_{1 \mathrm{j}}\right)} \\
=\frac{13 \times 480859-2410 \times 2611}{13 \times 489038-2410^{2}} \\
\mathrm{~b} \chi_{1 \mathrm{j}}=\frac{6251167-629250}{6357494-5808100}=\frac{41343}{549394} \\
\mathrm{~b} \chi_{1 \mathrm{j}}=0.08 \\
=\frac{2 \mathrm{n} 611}{\mathrm{n}}-\frac{\mathrm{b} \chi_{1 \mathrm{j}} \Sigma \chi_{1 \mathrm{j}}}{\mathrm{n}}=200.85-14.83 \\
\frac{\alpha \chi_{1 \mathrm{j}}=18.602}{0} \times 2410
\end{gathered}
$$

The regression equation for the influence of emotionally intelligent marketer with choice of market segment is: 


$$
\begin{aligned}
\mathrm{y} \chi_{1 j} & =\alpha \chi_{1 j}+b \chi_{1 j} \chi_{1 j} \\
& =186.02+0.08
\end{aligned}
$$

The coefficient of correlation for this influence is

$$
\gamma_{\mathrm{X} 1 \mathrm{j}}=\frac{n \sum x_{1 j} y-\sum x_{1 j} \sum y}{\sqrt{n \sum x_{1 j}^{2}-\left(\sum x_{1 j}\right)^{2}} \times \sqrt{n \sum y^{2}-\left(\sum y\right)^{2}}}
$$

$\mathrm{n} \Sigma \mathrm{y}^{2}-(\Sigma \mathrm{y})^{2}$ is already established above.

$$
\begin{aligned}
\mathrm{n} \Sigma \mathrm{y}^{2}-(\Sigma \mathrm{y})^{2} & =13 \times 1149439-2611^{2} \\
=11494390 & -6817321=4677069 \\
\gamma_{\mathrm{x} 1 \mathrm{j}} & =\frac{755101.2}{\sqrt{549394} \times \sqrt{4677069}} \\
& =\frac{755101.2}{16029.8236} \\
& =.471060
\end{aligned}
$$

$\therefore \gamma_{\mathrm{X} 1 \mathrm{j}}^{2}=.471060$ i.e. the coefficient of determination

for $\mathrm{y}: \chi_{1 \mathrm{j}}$

Furthermore, the regression $\mathrm{y}$ on $\chi_{2 \mathrm{j}}$ (emotional intelligence: market targeting) is determined resulting in:

$$
\begin{aligned}
\mathrm{y}_{\mathrm{x} 2 \mathrm{j}} & =\alpha_{\mathrm{x} 2 \mathrm{j}}+\mathrm{b}_{\mathrm{x} 2 \mathrm{j}} \mathrm{x}_{2 \mathrm{j}} \\
& =\alpha_{\mathrm{x} 2 \mathrm{j}}-\mathrm{b}_{\mathrm{x} 2 \mathrm{j}} \mathrm{x}_{2 \mathrm{j}} \\
\frac{\Sigma \mathrm{y}-\mathrm{b}_{\mathrm{x} 2 \mathrm{j}} \Sigma_{\mathrm{x} 2 \mathrm{j}}}{\mathrm{n}} & \frac{2611}{13}+4.712+\frac{3177}{13} \\
& =200.84615+0.249097 \mathrm{x}_{2 \mathrm{j}} \\
& =\gamma_{\mathrm{x} 2}{ }^{2} \mathrm{j}
\end{aligned}
$$

This present a two - dimension scattergram for three variables, in figure 1 as follows:

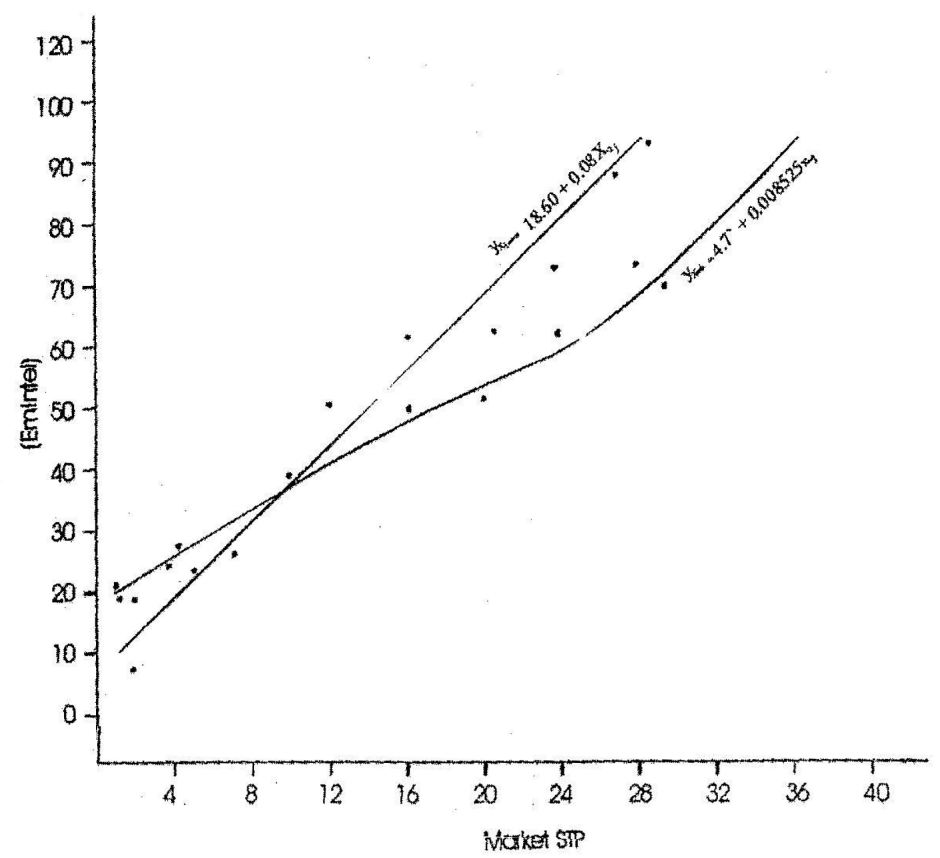

Figure 1. Scattergram of Emintel influence on choice of market segment and relationship with market target and positioning $\left(\mathrm{y}: \mathrm{x}^{1} \mathrm{j}, \mathrm{x}_{2} \mathrm{j}\right)$ 


\section{Appendix}

\section{Further analysis of data}

The multiple regression: $\mathrm{y}: \chi_{1 \mathrm{j}}$ and $\chi_{2 \mathrm{j}}$ used the three factors in normal equations and data in table 7 above, thus:

$2611=13 \mathrm{a}+2410 \mathrm{~b} 1 \mathrm{j}+3177 \mathrm{~b} 2 \mathrm{j}$

$480,859=2410 \mathrm{~b}_{1 \mathrm{j}}+489,038 \mathrm{~b} 1 \mathrm{j}+568,923 \mathrm{~b} 2 \mathrm{j}$

$589,365=31774+568,923 b 2 j+866,703 b 2 j$

Apply standard simultaneous equations to derive coefficients values from the equations

$\mathrm{y}=\mathrm{a}+\mathrm{b} 1 \mathrm{X} 1+\mathrm{b} 2 \mathrm{X} 2$

$\mathrm{y}=18.60+0.08 \chi_{1 j}+4.710+0.08525 \chi_{2 j}$

To test the hypothesis of influence of emotional intelligence with choice of market segment

$y=18.60+0.08 \times \frac{13}{3} \times 2611$

$=49.47 \%$ emintel influence over market segment in Abuja, Kano, Lagos and Port Harcourt respectively.

Using $\mathrm{R}^{2}$ (coefficient of multiple determination)

$\mathrm{R}^{2}=(18.6 \times 2611)+(0.08 \times 480,859)+$

$(0.08525 \times 589365)-2611^{2} / 13$

\section{$1149,439-2611^{2} / 1$}

$=.2578225614$

$\approx 26 \%$ relationship at $\mathrm{p}<0.05$

Summary of coefficients determination

$\gamma^{2}{ }_{\mathrm{Xlj}}=0.47106$

$\gamma^{2}{ }^{2 j}=0.494$

$\mathrm{R}^{2}=0.2578$

Model of emotional intelligence and market Segmentation, targeting and positioning (STP)

Model 1

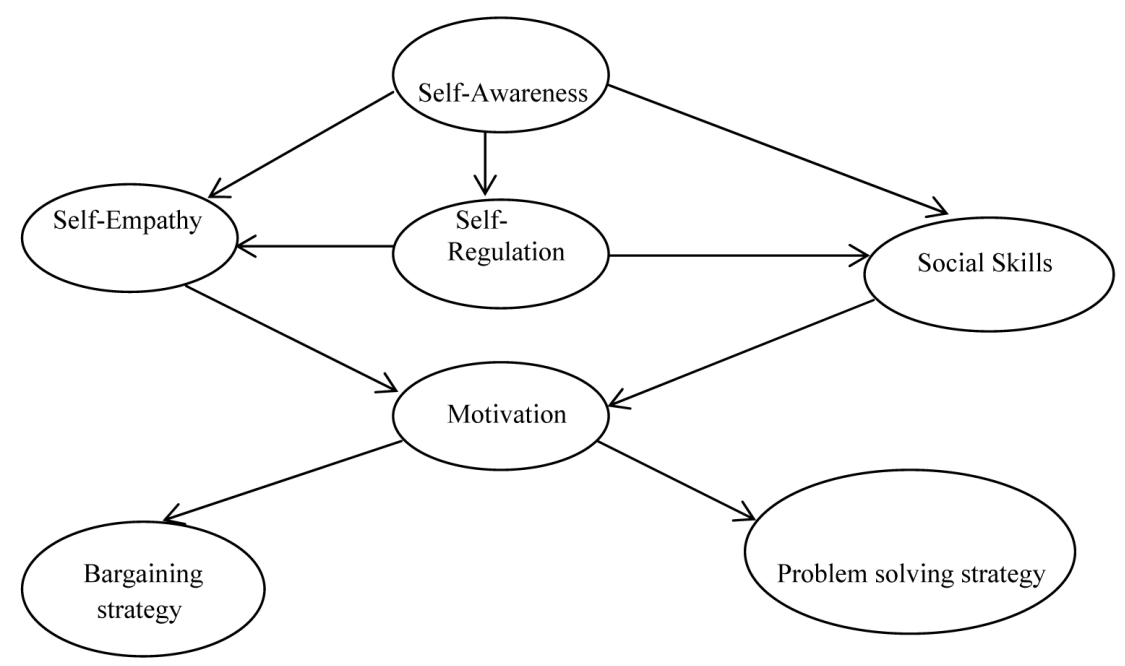

Source: Adapted from Rahim and Psenicka (2003).

Based on Rahim and Psenicka's model, the third model was developed by these researchers, thus:

Emotional intelligence and market segmentation architecture model 
Model 2

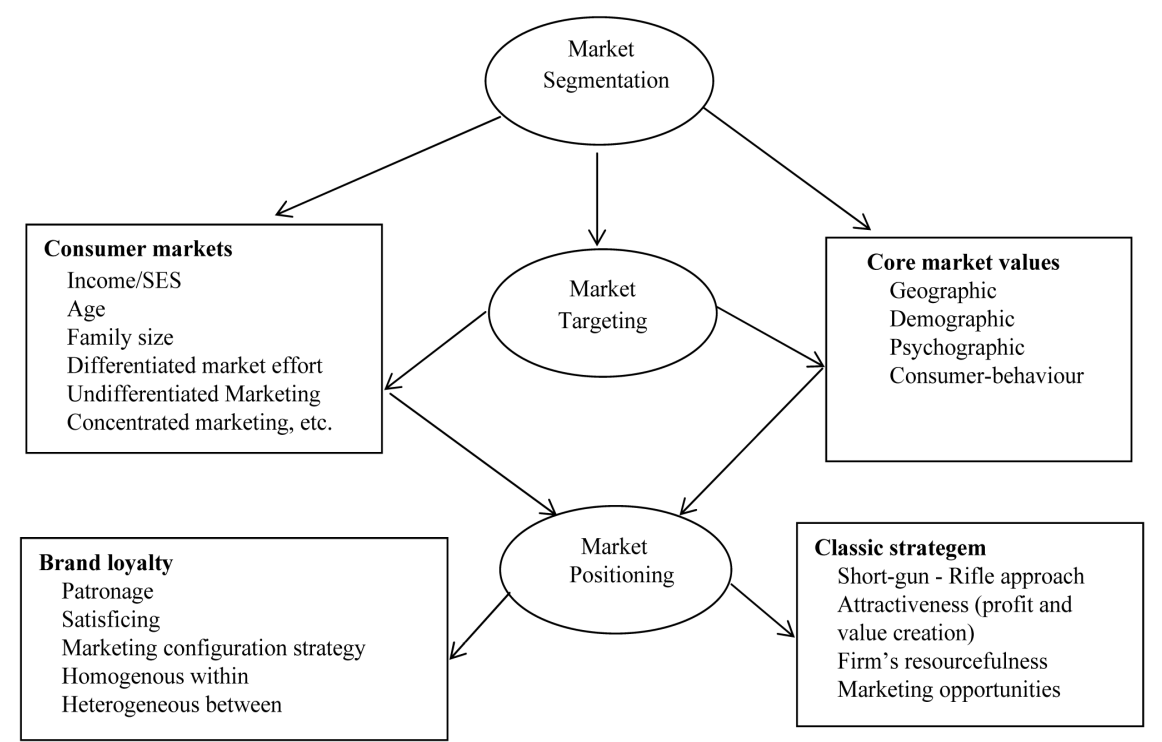

\section{Model 3}

The third model defines the variables of interest using a popular regression equation derived from Rahim and Psenicka above thus

$$
Y=b_{o}+b_{1} \chi_{1 j}+b_{2} \chi_{2 j}+b_{3} \chi_{3 j}
$$

Where $\mathrm{Y}=$ Emotional intelligence (Emintel)

$\chi_{1}=$ Market segmentation

$\mathrm{j}=$ Geographic (nations/cities)

1) Demographic (SES, family size, age, etc.)

2) Psychographic (lifestyle, values, personality, patronage, brand loyalty, etc.)

3) Consumer behavior (attitudes, loyalty, readiness, post-purchase consonant)

$\chi_{2}=$ Market Targeting

$\mathrm{J}=$ Wealthy group, retired group, risk preference group, socialite group, needs-based group, market attractiveness, market opportunities, growth and access.

$\chi_{3}=$ Market Positioning

$\mathrm{J}=$ Product differentiation, market undifferentiating and concentration,

1) Market cannibalization

2) Key consumers perception, unique and customized attributes and judgment,

3) Perceptual map, conservation and expressive appeal.

$b_{1} \ldots b_{3}=$ Regression coefficients

$\mathrm{e}_{1}=$ Error term

The linear equation model with multiple regressions was chosen based on the effective strength of the coefficients of multiple determinations and the number of significant variables. 